\title{
Wounds on Rapanea melanophloeos provide habitat for a large diversity of Ophiostomatales including four new species
}

\author{
Tendai Musvuugwa \\ Department of Botany and Zoology, Stellenbosch University, Private Bag X1, Stellenbosch, 7600, \\ South Africa
}

Z. Wilhelm de Beer

Department of Microbiology and Plant Pathology, Forestry and Agricultural Biotechnology Institute (FABI), University of Pretoria, Pretoria 0002, South Africa

Tuan A. Duong

Department of Genetics, Forestry and Agricultural Biotechnology Institute (FABI), University of Pretoria, Pretoria 0002, South Africa

Léanne L. Dreyer

Department of Botany and Zoology, Stellenbosch University, Private Bag X1, Stellenbosch, 7600, South Africa and DSTNRF Centre of Excellence in Tree Health Biotechnology (CTHB), Forestry and Agricultural Biotechnology Institute (FABI), Department of Microbiology and Plant Pathology, University of Pretoria, Private Bag X20, Hatfield, Pretoria, 0028, South Africa

\section{Kenneth Oberlander}

Institute of Botany, Academy of Sciences, Průhonice, CZ - 252 43, Czech Republic and Department of Conservation Ecology and Entomology, Stellenbosch University, Private Bag X1, Stellenbosch, 7600, South Africa

\section{Francois Roets}

Department of Conservation Ecology and Entomology, Stellenbosch University, Private Bag X1, Stellenbosch, 7600, South Africa and DSTARF Centre of Excellence in Tree Health Biotechnology (CTHB), Forestry and Agricultural Biotechnology Institute (FABI), Department of Microbiology and Plant Pathology, University of Pretoria, Private Bag X20, Hatfield, Pretoria, 0028, South Africa

Corresponding author Francois Roets, email address: fr@sun.ac.za, telephone: +2721 808 2635, fax: $+27218084821$

\footnotetext{
Abstract Rapanea melanophloeos, an important canopy tree in Afromontane forests, is commonly utilised for medicinal bark harvesting. Wounds created from these activities provide entrance for many fungi, including arthropod-associated members of the Ophiostomatales and Microascales (ophiostomatoid fungi). In this study we assess the diversity of wound-associated Ophiostomatales on storm-damaged $R$. melanophloeos trees in the Afromontane forests of South Africa. Five species were
} 
identified based on micro-morphological and molecular phylogenetic analyses. These included Ophiostoma stenoceras and four newly described taxa Sporothrix itsvoense sp. nov., S. rapaneae sp. nov., S. utae sp. nov. and O. noisomeae sp. nov. Four of these are members of the S. schenckii-O. stenoceras complex (O. stenoceras, S. itsvoense sp. nov., S. rapaneae sp. nov., S. utae) while O. noisomeae groups basal in the Ophiostomatales alongside the S. lignivora complex and Graphilbum. In addition to other taxa known from this host, the present study shows that there is a rich, yet still poorly explored, diversity of Ophiostomatales associated with $R$. melanophloeos in Afromontane forests. More taxa are likely to be discovered with increased research effort. These must be assessed in terms of pathogenicity towards this ecologically and economically important tree.

Key words Afromonatane forests $\cdot$ Ophiostoma $\cdot$ Rapanea $\cdot$ Sporothrix

Acknowledgements The authors thank the DSTNRF Centre of Excellence in Tree Health Biotechnology (CHTB) for financial support and the South African National Parks Board (SANPARKS) and Western Cape Nature Conservation Board for issuing the necessary collecting permits. We are also grateful to Netsai Machingambi, PC Benade and Dewidine van der Colff for assistance with field work and Jane Forrester for permission to work on trees in the Harold Porter National Botanical Garden.

\section{Introduction}

Ophiostomatoid fungi represent genera that are morphologically similar, although not phylogenetically closely related (De Beer et al. 2013a). The group includes genera such as Ophiostoma Syd., Ceratocystiopsis H.P. Upadhyay \& W.B. Kendr., Graphilbum H.P. Upadhyay \& W.B. Kendr., Raffaelea Arx \& Hennebert, Fragosphaeria Shear and Leptographium Lagerb. \& Melin in the Ophiostomatales, and Ceratocystis Ellis \& Halst., Knoxdaviesia M.J. Wingf., P.S. van Wyk \& Marasas, Cornuvesica Viljoen, M.J. Wingf. \& Jacobs, Custingophora Stolk, Hennebert \& Klopotek, Sphaeronaemella P. Karst. and Graphium Corda in the Microascales (De Beer et al. 2013b). A common morphological trait shared by these fungi is globose ascomata with usually elongated necks that give rise to masses of sticky spores at their tips, an entomochoric adaptation to allow spore dispersal via arthropods (Malloch and Blackwell 1993). 
Members of the Ophiostomatales contain some of the best known tree pathogens. Some of these are responsible for very high rates of tree mortality, which has led to significant losses to forests (Brasier and Buck 2001; Harrington et al. 2008; Heybroek 1993; Wingfiled et al. 1993). Well-documented examples include Raffaelea quercivora Kubono et Shin. Ito, responsible for oak die-back and mortality of Japanese oak trees (Kubono and Ito 2002) as well as Ophiostoma ulmi (Buismann) Nannf and O. novo-ulmi Brasier, responsible for the Dutch Elm disease pandemics in Europe and the United States of America (Brasier 2000, 2008; Pipe et al. 2000; Wingfield et al. 1993). A number of plant pathogenic Leptographium species have also been reported. Examples include L. procerum (W.B. Kendr) M.J. Wingf. associated with pine root disease (Jacobs and Wingfield 2001), L. calophylli (Wiehe) JF. Webber, K. Jacobs \& MJ. Wingfield that causes vascular wilt disease of takamaka trees (Webber et al. 1999) and L. wageneri (Goheen \& F.W. Cobb) T.C. Harr. that causes black stain root disease on conifers (Harrington 1993). Some taxa are not pathogenic, or just weakly pathogenic, but may also cause significant problems in the forestry industry. For example, many species of Ophiostoma are responsible for sapstain of lumber and pulpwood, which degrades wood quality and results in substantial economic losses (Seifert 1993).

Several Ophiostomatales infect their hosts via wounds (Wingfield et al. 1993). Such wounds are caused by various agents, including animals (e.g. arthropods), natural phenomena such as hail, frost or heavy rains as well as human practises such as bark stripping and silviculture (Kamgan Nkuekam et al. 2008; Moller and Devay 1968; Vermeulen et al. 2012). Ophiostoma minus, for example, colonises wounds created through mechanical injury or partial debarking (Gibbs 1993). Fungi are transported to these wounds through agents such as arthropods (Harrington and Wingfield 1998; Hinds 1972; Moller and Devay 1968) or wind in the case of asexual states of Sporothrix Hektoen \& C.F. Perkins with dry spores (Wingfield et al. 1993). Despite the importance of Ophiostomatales as tree pathogens, reports of these fungi in Africa, including South Africa, are very limited. A few studies focused on taxa associated with native tree hosts (De Beer et al. 2003; Kamgan Nkuekam et al. 2008; Marais and Wingfield 1997, 2001; Roets et al. 2006, 2008), but most knowledge of the fungi in South Africa is based on species associated with non-native host tree species (De Beer et al. 2003; Kamgan Nkuekam et al. 2012; Zhou et al. 2006). 
Rapanea melanophloeos (L.) Mez is one of the more abundant and very important canopy trees found in these forests. It is a fast growing, evergreen forest pioneer, but can also be found as large trees in mature forests (Van Wyk and Van Wyk 1997). The bark of this plant is often harvested for medicinal purposes, creating wounds through which fungi can infect (Vermeulen et al. 2012). In South Africa, wound-associated ophiostomatoid fungi have been collected from this species, some of which have proven to be pathogenic (Kamgan Nkuekam et al. 2008). For example, Ceratocystis tsitsikammensis Kamg. Nkuek. \& Jol. Roux was isolated from wounds on $R$. melanophloeos in the Tsitsikamma forests and could kill seedlings of this species within a relatively short period (Kamgan Nkuekam et al. 2008). Despite pathogens being critically important to ecosystem function (Castello et al. 1995), there has been little focus on them, especially on those associated with native trees in the Afromontane forests of South Africa (Taylor 2001). The recently described virulent pathogen, Immersiporthe knoxdaviesiana S.F. Chen, M.J. Wingf. \& Jol. Roux, which causes the death of Rapanea trees in the Harold Porter Botanical garden (Chen et al. 2013), illustrates the importance of documenting these fungal taxa.

In addition to $C$. tsitsikammensis, only a few other wound infecting ophiostomatoid fungi have been isolated from $R$. melanophloeos. These include a Graphilbum fragrans (Mathiesen-Käärik) Z.W. de Beer, Seifert \& M.J. Wingf. - like fungus and O. quercus (Georgévitch) Nannf. (Kamgan Nkuekam et al. 2008). More recently, a few beetle associated taxa have also been identified from this host. Raffaelea rapaneae T. Musvuugwa, Z.W. de Beer, L.L. Dreyer \& F. Roets was isolated from a Platypodinae beetle and Sporothrix aemulophila T. Musvuugwa, Z.W. de Beer, L.L. Dreyer \& F. Roets was associated with Xyleborinus aemulus Wollaston (Scolytinae) on R. melanophloeos (Musvuugwa et al. 2015). This tree species may be under considerable threat from fungi, and there is thus an urgent need to study taxa associated with $R$. melanophloeos in their natural habitats. The objective of this study was therefore to assess the diversity of wound-associated Ophiostomatales on storm damaged Rapanea trees at various sites across its distribution range in South Africa. 


\section{Materials and methods}

\section{Sampling of plant material and fungal isolates}

The Afromontane forests of South Africa are found from Table Mountain in the extreme southwest of the Cape Floristic Region, are most extensive in the Tsitsikamma area of the southern Cape coastal regions, and extend northwards along the coastal mountains into the KwaZulu-Natal Province (Lubke and McKenzie 1996). They occur as small fragmented patches within river valleys, on mountains, foothills and on coastal platforms, and represent the outliers of the tropical African Afromontane forests (Turpie et al. 2003).

Wounds on Rapanea melanophloeos were surveyed in the Harold Porter National Botanical Garden (S 34²0'54" E 1855'31"), Groenkop Forest Reserve (S

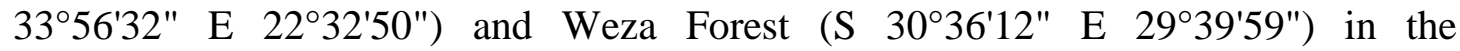
Afromontane forests of the Cape Floristic Region and KwaZulu-Natal Province. All wounds were presumably caused by weather damage during storms. Bark and wood samples were collected from wounds during late winter (August) of 2010 - 2012, by using a hammer and chisel or machete to cut off pieces measuring approximately $5 \mathrm{~cm}$ $x 5 \mathrm{~cm}$ and not more than $3 \mathrm{~cm}$ deep. These samples were collected from fresh wounds characterized by oozing sap and that showed signs of fungal growth when examined using a field magnifying glass. In total, 45 bark and wood samples were collected, each from a different wound on a different tree. The samples were placed in separate sampling bags and transferred to the laboratory where they were examined for the presence of members of the Ophiostomatales using a Leica EZ4 microscope (Wetzlar, Germany). When fungi were present, masses of ascospores and/or conidia were collected from the apices of sporulating structures using a sterile needle. They were transferred to $2 \%$ malt extract agar (MEA) emended with $0.05 \mathrm{~g}$ cycloheximide $1^{-1}$ to select for members of the Ophiostomatales (Harrington 1981). When no fungi were present, collected material was placed in moisture chambers (resealable plastic bags with $\mathrm{ddH}_{2} \mathrm{O}$-moistened paper towels $)$ at room temperature $\left(\sim 23^{\circ} \mathrm{C}\right)$ in the dark for up to four weeks to stimulate fungal growth, after which fungal isolations were performed as outlined above. Isolates were stored in the dark at room temperature and examined daily for fungal growth. Isolates resembling anamorphic states of Ophiostomatales were purified by transferring single hyphal tips from the edges of actively growing fungal colonies to fresh MEA plates. All purified cultures were 
maintained on petri dishes containing MEA at $4^{\circ} \mathrm{C}$ until further use. Representative cultures of all morpho-types collected in this study are maintained in the culture collection (CMW) of the Forestry and Agricultural Biotechnology Institute (FABI) at the University of Pretoria, South Africa and in the culture collection of the Centaalbureau voor Schimmelcultures (CBS), Utrecht in the Netherlands. Herbarium specimens of the anamorph and teleomorph states belonging to the new species were deposited in the National Fungus Collection (PREM), Pretoria, South Africa.

\section{Morphological characterisation}

Where available, ascocarps and ascospores of members of the Ophiostomatales were collected from plant material, mounted in clear lactophenol on microscope slides and studied using a Leica EZ4 microscope. Twenty-five measurements of all morphologically and taxonomically useful structures were made of isolates suspected to represent new taxa. The maximum and minimum measurements for each taxonomically useful character were noted and means ( \pm standard deviation) were calculated. Photographs of the structures were taken using a Leica digital camera mounted on the microscope.

\section{Fungal identification}

Based on colony and micro-morphological characteristics, all fungal cultures suspected to belong to the Ophiostomatales were grouped into morphotypes. Three or more pure isolates collected in this study, representing each morphotype, were randomly chosen for DNA sequence comparisons (Table 1). For DNA extraction, fungal mycelium was harvested from edges of 2 week old actively growing colonies of pure cultures on MEA using a sterile scalpel. DNA was extracted from the fungal mycelium using the PrepMan® Ultra sample preparation reagent following the manufacturer's instructions. To amplify the nuclear ribosomal internal transcribed spacer region (ITS1, ITS2), including the 5.8S gene region of the rDNA, the primers ITS1F (Gardes and Bruns 1993) and ITS4 (White et al. 1990) were used and where amplification was difficult, ITS1F was replaced with ITS1 (White et al. 1990). Preliminary placement of fungi using ITS was used as baseline to decide on additional markers to amplify for each fungal morpho-type (Table 1). For amplification of part of the beta-tubulin $(\beta \mathrm{T})$ gene, the primers Bt2a and Bt2b (Glass and Donaldson 1995) 
were used, which were replaced in some cases with the primer pair $\mathrm{Bt} 2 \mathrm{~b}$ and $\mathrm{T} 10$ (O'Donnell and Cigelnik 1997). PCR amplification of the calmodulin gene region (CAL) was done using the primers CL2F and CL2R (Duong et al. 2012) and in cases where amplification was difficult, CL2R2 (Duong et al. 2012) was used instead of CL2R. For each marker, PCR reaction components, volumes and conditions followed those described by Musvuugwa et al. (2015).

Table 1 Culture collection and GenBank accession numbers for strains of ophiostomatoid fungi isolated from Rapanea melanophloeos that were sequenced in this study.

\begin{tabular}{|c|c|c|c|c|c|c|c|c|}
\hline $\begin{array}{l}\text { Fungal } \\
\text { species }\end{array}$ & $\begin{array}{l}\text { Isolate } \\
\text { numbers }\end{array}$ & Type status & ITS & $\beta T$ & CAL & $\begin{array}{l}\text { OTU } \\
\text { number }\end{array}$ & $\begin{array}{l}\text { \% frequency of } \\
\text { occurrence }\end{array}$ & Collection site \\
\hline \multirow[t]{4}{*}{ O. noisomeae } & CMW 40329 & Ex-paratype & KU639634 & KU639630 & KU639611 & 4 & $26 \%$ & Weza Forest \\
\hline & CMW 40326 & Ex-holotype & KU639631 & KU639628 & & 4 & & \\
\hline & CMW 40327 & Ex-paratype & KU639632 & & KU639612 & 4 & & \\
\hline & CMW 40328 & Ex-paratype & KU639633 & KU639629 & KU639610 & 4 & & \\
\hline \multirow[t]{3}{*}{ O. stenoceras } & CMW 40372 & & KU595580 & KU639619 & KU639613 & 5 & $13 \%$ & Weza Forest \\
\hline & CMW 40373 & & KU595579 & KU639620 & KU639614 & 5 & & \\
\hline & CMW 40374 & & & KU639612 & KU639615 & 5 & & \\
\hline \multirow[t]{3}{*}{ S. itsvoense } & CMW 40370 & Ex-holotype & & KU639625 & & 1 & $21 \%$ & $\mathrm{HPNBG}^{1}$ \\
\hline & pending & Ex-paratype & KU595582 & KU639626 & & 1 & & \\
\hline & CMW 40371 & Ex-paratype & & KU639628 & & 1 & & \\
\hline \multirow[t]{3}{*}{ S. rapaneae } & CMW 40367 & Ex-paratype & & & KU639608 & 2 & $18 \%$ & Groenkop Fore \\
\hline & CMW40368 & Ex-paratype & KU595581 & KU639623 & & 2 & & \\
\hline & CMW40369 & Ex-holotype & KU595583 & KU639624 & KU639609 & 2 & & \\
\hline \multirow[t]{3}{*}{ S. utae } & CMW 40316 & Ex-paratype & KU595577 & KU639616 & KU639605 & 3 & $23 \%$ & Weza Forest \\
\hline & CMW 40317 & Ex-paratype & KU595578 & KU639617 & KU639606 & 3 & & \\
\hline & CMW 40318 & Ex-holotype & KU595576 & KU639618 & KU639607 & 3 & & \\
\hline
\end{tabular}

${ }^{1} \mathrm{CMW}=$ Culture Collection of Michael Wingfield, Forestry and Agricultural Biotechnology Institute (FABI), University of Pretoria

${ }^{2}$ HPNBG $=$ Harold Porter National Botanical Garden

All products were amplified using a Gene Amp ${ }^{\mathrm{R}}$, PCR System 2700 thermal cycler (Applied Biosystems, Foster City, U.S.A.). Amplified products were separated using agarose gel electrophoresis stained with GelRed (Biotium, Inc., California, USA) and visualized under ultraviolet light. All amplified PCR products were cleaned using EXOSAP-IT (USB Corporation, Cleveland, Ohio, U.S.A.) following the manufacturer's instructions. Purified fragments were sequenced using the respective PCR primers and the Big Dye ${ }^{\mathrm{TM}}$ Terminator v3.0 cycle sequencing premix kit (Applied Biosystems, Foster City, CA, U.S.A.) and analysed on an ABI PRISM ${ }^{\mathrm{TM}}$ 3100 Genetic Analyser (Applied Biosystems, Foster City, CA, U.S.A.). PCR sequencing reaction volumes were the same as those used by Musvuugwa et al. (2015) and the same primers used for PCR amplifications were used to sequence both 
DNA strands. Resultant sequences were edited and used to construct consensus sequences using the CLC Genomics Workbench software package (CLCBio, Aarhus, Denmark).

BLAST algorithm (Altschul et al. 1990) searches were performed using ITS sequences to preliminary identify the fungal isolates and to compare and find similarities with sequences published on the GenBank sequence database (http://www.ncbi.nlm.nih.gov). Sequences of closely related taxa to isolates collected in this study (Table 1) were downloaded from the GenBank database and aligned with sequences generated in this study using MAFFT 6 (Katoh and Toh 2008) for each data set. Maximum likelihood (ML) and Bayesian inference (BI) analyses were conducted on all the datasets created. The online version of PhyML 3.0 (Guindon and Gascuel 2003, http://www.atgc-montpellier.fr/phyml) was used to perform ML analyses. To determine the best fit substitution models jModelTest 0.1.1 (Posada 2008) was used using Akaike information criteria (Akaike 1974). Statistical confidence support values for nodes were determined using 1000 replication bootstrap analyses. MrBayes 3.1.2 (Ronquist and Huelsenbeck 2003) was used to perform BI analyses employing a Markov chain Monte Carlo approach (MCMC). MrBayes's rjMCMC mixture model was used. Two Markov chains independent of each other were run simultaneously for 10 million generations starting from a random tree. A sample frequency of 2000 was implemented and the burn-in trees (first 2500000 generations) were discarded. The remaining trees were pooled into a $50 \%$ majority rule consensus tree.

\section{Growth in culture}

Optimal growth conditions of potential new species were determined by removing a disk of agar (10 mm diam) covered with mycelium from edges of actively growing, one week old cultures and placing these upside down in the centres of $90 \mathrm{~mm}$ fresh Petri dishes containing $20 \mathrm{~mL}$ MEA. Petri dishes were incubated in the dark at different temperatures ranging from $5^{\circ} \mathrm{C}$ to $35^{\circ} \mathrm{C}$ (at intervals of $5^{\circ} \mathrm{C}$ ) for a period of 10 days. Five replicates were used for each temperature interval. After 10 days, two colony diameters perpendicular to each other were measured for each colony, these measurements were averaged for each plate and then averaged for each species $( \pm$ standard deviation). 


\section{Results}

Fungal isolates and morphological characterisation

In total, 39 isolates morphologically resembling fungi in the Ophiostomatales were obtained from wounds on several $R$. melanonophloeos trees sampled at the different sites (Table 1). Based on colony characteristics and micro-morphology, the isolates collected in this study were grouped into five different morphotypes that all resembled species in the Sporothrix schenckii-O. stenoceras complex (De Beer and Wingfield 2013). Of the 39 isolates obtained, eight were from morphotype 1 collected from Harold Porter National Botanical Garden (Table 1). These were characterised by producing perithecia (produced on plant material only) with brownish ascomatal bases with hyphal ornamentation and produced whitish to cream-coloured colonies that were fluffy at the centre on MEA. Morphotype 2 consisted of seven isolates collected from the Groenkop Forest characterised by producing black ascomata (on plant material only), without hyphal ornamentation and white fluffy colonies on MEA. The third morphotype (morphotype 3) identified included nine isolates collected from Weza Forest that were characterised by producing black ascomata (produced on plant material only) and white colonies that grew slowly compared to other morphotypes. Morphotype 4 comprised of 10 isolates that were also collected from Weza Forest (Table 1). They were characterised by producing black ascomata (on plant material only) and white colonies on MEA that turned blackish with age. Five isolates of morphotype 5 also from Weza Forest (Table 1) were characterised by producing black ascomata in culture after three weeks of incubation and colonies that either became dark brown or remained white with age. The frequency of occurrence per wound varied between $13 \%$ for morphotype 5 and $26 \%$ for morphotype 4 (Table 1).

\section{Phylogenetic analyses}

All fungal morphotypes were confirmed members of the Ophiostomatales based on initial placement using ITS data and represented discrete operational taxonomic units (OTU's). These were therefore further characterised using ITS, $\beta \mathrm{T}$ and CAL data. Alignment of data sets resulted in 84 taxa and 785 characters for ITS, 73 taxa and 280 characters for $\beta$ T and 58 taxa and 720 characters for CAL. Statistical values obtained from the analyses of the different data sets are summarized in Table 2, along with the substitution models chosen. GenBank accession numbers for other taxa used in the 
phylogenetic analyses are presented on the respective trees for each data set (Figs. 1$3)$.

Table 2. Parameters used and statistical values obtained from Maximum Likelihood (ML) and Bayesian Inference (BI) analyses of the three datasets

\begin{tabular}{|c|c|c|c|c|}
\hline & Dataset & ITS & $\beta$ T & CAL \\
\hline & Figure & Fig. 1 & Fig. 2 & Fig. 3 \\
\hline \multirow[t]{5}{*}{ ML } & Substitution model & $\mathrm{GTR}+\mathrm{I}+\mathrm{G}$ & $\mathrm{K} 80+\mathrm{G}$ & $\mathrm{HKY}+\mathrm{I}+\mathrm{G}$ \\
\hline & Gamma shape & 0.469 & 0.188 & 1.542 \\
\hline & Log-Likelihood & -9084.95 & -2040.08 & -3891.25 \\
\hline & $\begin{array}{l}\text { Relative rate } \\
\text { parameters }\end{array}$ & 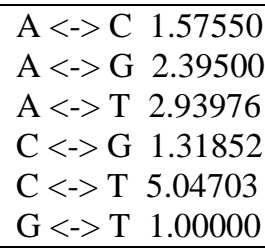 & & \\
\hline & Nucleotide frequencies & $\begin{array}{l}-f(A)=0.16651 \\
-f(C)=0.35674 \\
-f(G)=0.28242 \\
-f(T)=0.19433\end{array}$ & $\begin{array}{l}-\mathrm{f}(\mathrm{A})=0.25000 \\
-\mathrm{f}(\mathrm{C})=0.25000 \\
-\mathrm{f}(\mathrm{G})=0.25000 \\
-\mathrm{f}(\mathrm{T})=0.25000\end{array}$ & $\begin{aligned}-\mathrm{f}(\mathrm{A}) & =0.24940 \\
-\mathrm{f}(\mathrm{C}) & =0.24091 \\
-\mathrm{f}(\mathrm{G}) & =0.29348 \\
-\mathrm{f}(\mathrm{T}) & =0.21622\end{aligned}$ \\
\hline \multirow[t]{7}{*}{ BI } & Likelihood & 9221.97 & -2240.28 & -4023.97 \\
\hline & $\begin{array}{l}\text { Average Effective } \\
\text { Sample Size of } \\
\text { Likelihood Value }\end{array}$ & 366 & 1368 & 1007 \\
\hline & $\begin{array}{l}\text { GTR Submodel } \\
\text { Probability }\end{array}$ & 0.24 & 0.12 & 0.3 \\
\hline & Model string & [123454] & [123323] & [121321] \\
\hline & Gamma shape & 1.05 & 0.21 & 1.46 \\
\hline & $\begin{array}{l}\text { Relative rate } \\
\text { parameters }\end{array}$ & $\begin{array}{l}\mathrm{A}<->\mathrm{C} \quad 0.10820 \\
\mathrm{~A}<->\mathrm{G} 0.16567 \\
\mathrm{~A}<->\mathrm{T} 0.21853 \\
\mathrm{C}<->\mathrm{G} 0.08272 \\
\mathrm{C}<->\mathrm{T} \quad 0.34801\end{array}$ & $\begin{array}{l}\mathrm{A}<->\mathrm{C} 0.16790 \\
\mathrm{~A}<->\mathrm{G} 0.27235 \\
\mathrm{~A}<->\mathrm{T} 0.09903 \\
\mathrm{C}<->\mathrm{G} 0.09205 \\
\mathrm{C}<->\mathrm{T} 0.28469\end{array}$ & $\begin{array}{l}\text { A }<->C \\
\text { A } 0.08443 \\
\text { A }<->\text { G } 0.34859 \\
\text { C<-> } 0.088760 .05901 \\
\text { C<-> T } 0.33305\end{array}$ \\
\hline & Nucleotide frequencies & $\begin{array}{l}\mathrm{pi}(\mathrm{A})=0.16187 \\
\mathrm{pi}(\mathrm{C})=0.36121 \\
\mathrm{pi}(\mathrm{G})=0.28583 \\
\mathrm{pi}(\mathrm{T})=0.19109\end{array}$ & $\begin{array}{l}\mathrm{pi}(\mathrm{A})=0.31424 \\
\mathrm{pi}(\mathrm{C})=0.20805 \\
\mathrm{pi}(\mathrm{G})=0.28989 \\
\mathrm{pi}(\mathrm{T})=0.18783\end{array}$ & $\begin{array}{l}\operatorname{pi}(\mathrm{A})=0.24319 \\
\mathrm{pi}(\mathrm{C})=0.24811 \\
\mathrm{pi}(\mathrm{G})=0.29685 \\
\operatorname{pi}(\mathrm{T})=0.21185\end{array}$ \\
\hline
\end{tabular}

For OTU 1 collected from the Harold Porter National Botanical Garden, phylogenetic analyses were only performed using ITS and $\beta$ T (Figs. 1 and 2) and could not be performed for the CAL gene region due to amplification failure. Analysis of this particular OTU (hereafter referred to as: Sporothrix itsvoense sp. nov.) using ITS data resulted in its isolates grouping together as a strongly supported distinct taxon sister to a clade comprising of S. aemulophila Musvuugwa, Z.W. de Beer, L.L. Dreyer \& F. Roets, O. candidum Kamgan-Nkuek., Jol. Roux \& Z. W. de Beer and the OTU from Groenkop forest collected in this study. Analyses using $\beta T$ data resulted in it grouping as a strongly supported distinct taxon sister to $S$. aemulophila. 


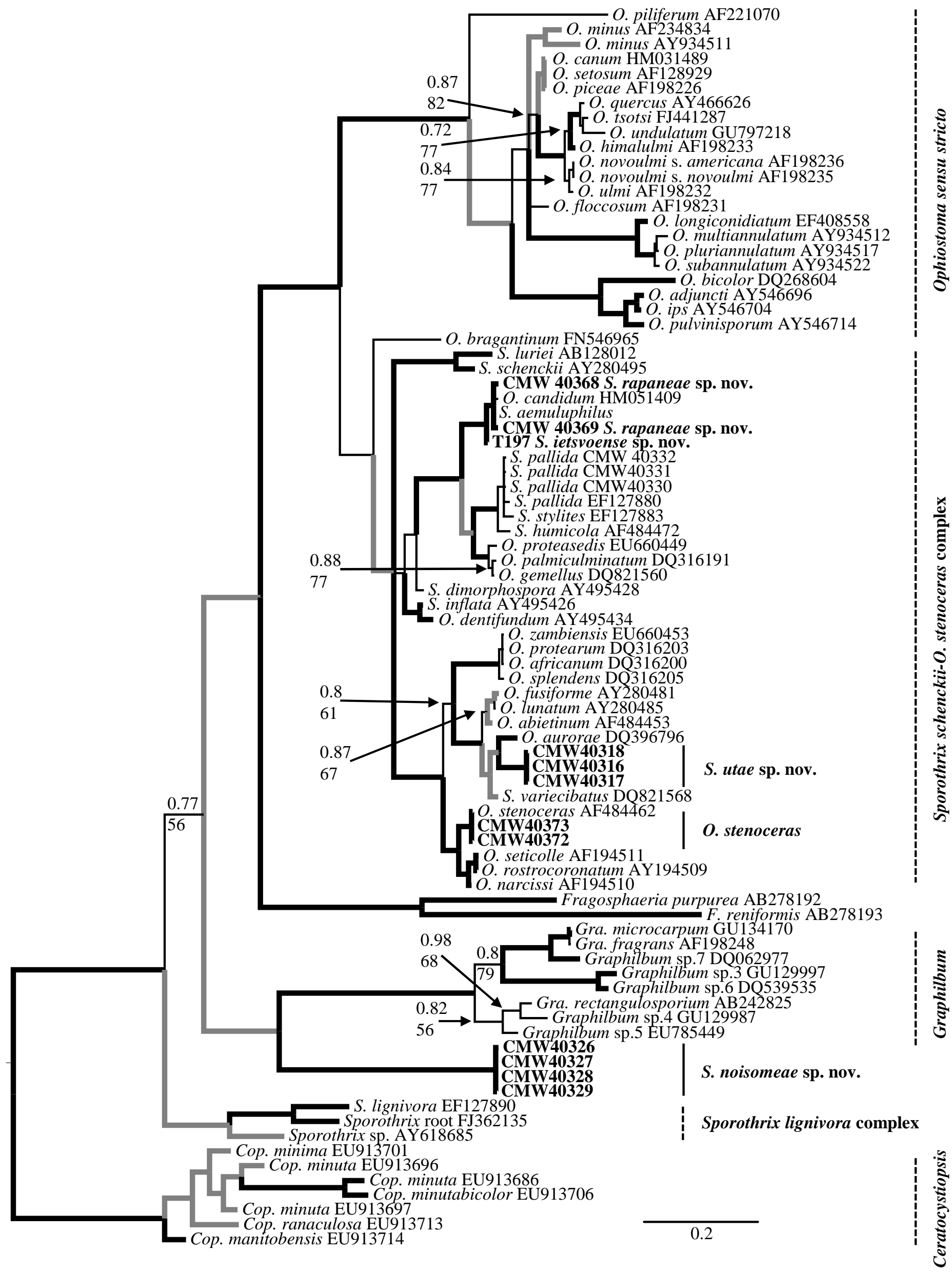

Fig. 1: Bayesian Inference consensus tree (ITS data) of taxa related to species isolated in the present study (bold type). Values above nodes indicate posterior probabilities obtained through Bayesian Inference. Values below nodes indicate bootstrap values (1000 replicates) obtained from Maximum Likelihood analysis. Other isolates [GenBank accession numbers and isolate numbers shown (when available)] were selected for comparative purposes. Dashed lines demarcate different genera or species complexes 


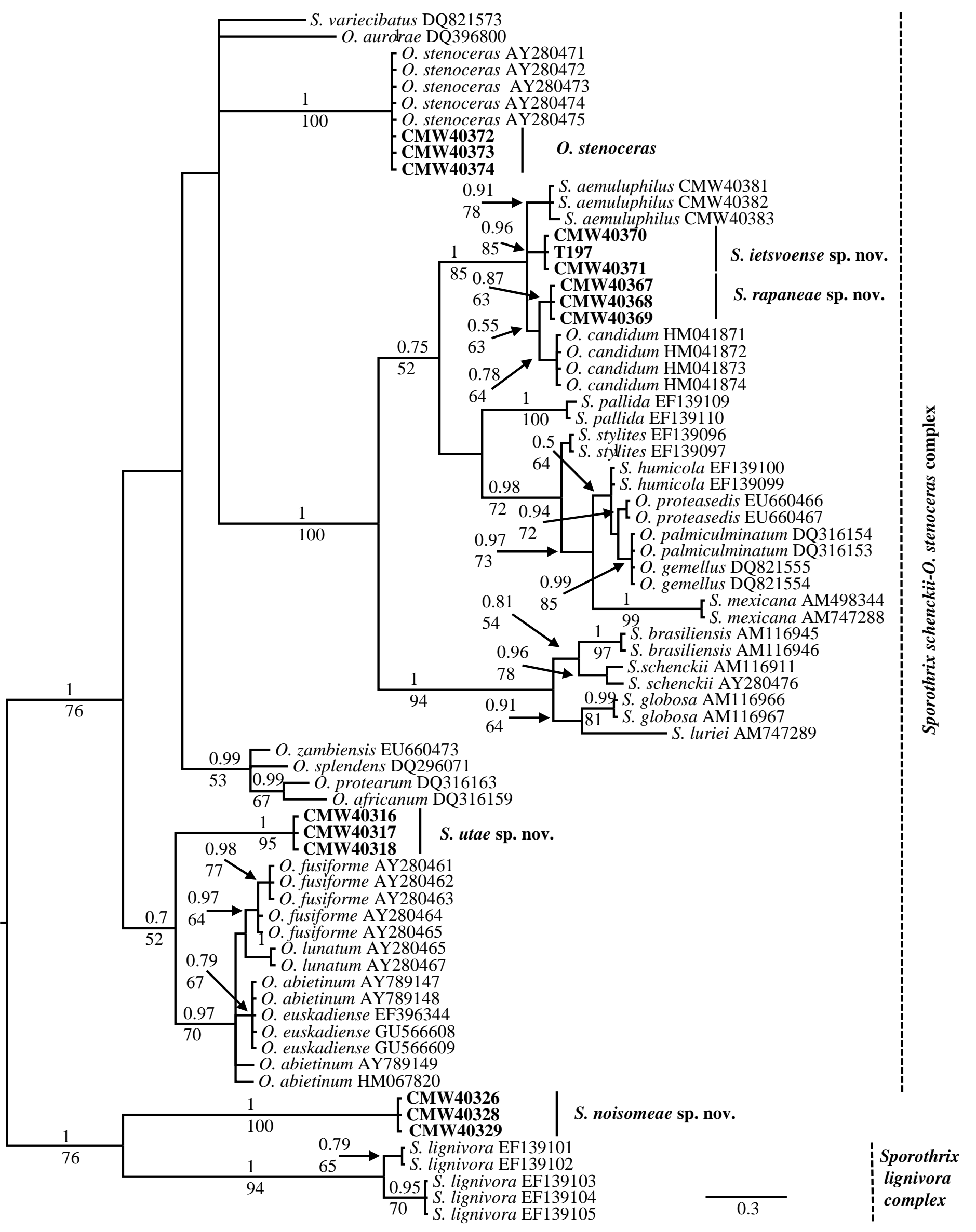

Fig. 2: Bayesian Inference consensus tree ( $\beta$ t data) of taxa related to species isolated in the present study (bold type). Values above nodes indicate posterior probabilities obtained through Bayesian Inference. Values below nodes indicate bootstrap values (1000 replicates) obtained from Maximum Likelihood analysis. Other isolates [GenBank accession numbers and isolate numbers shown (when available)] were selected for comparative purposes. Dashed lines demarcate different species complexes 


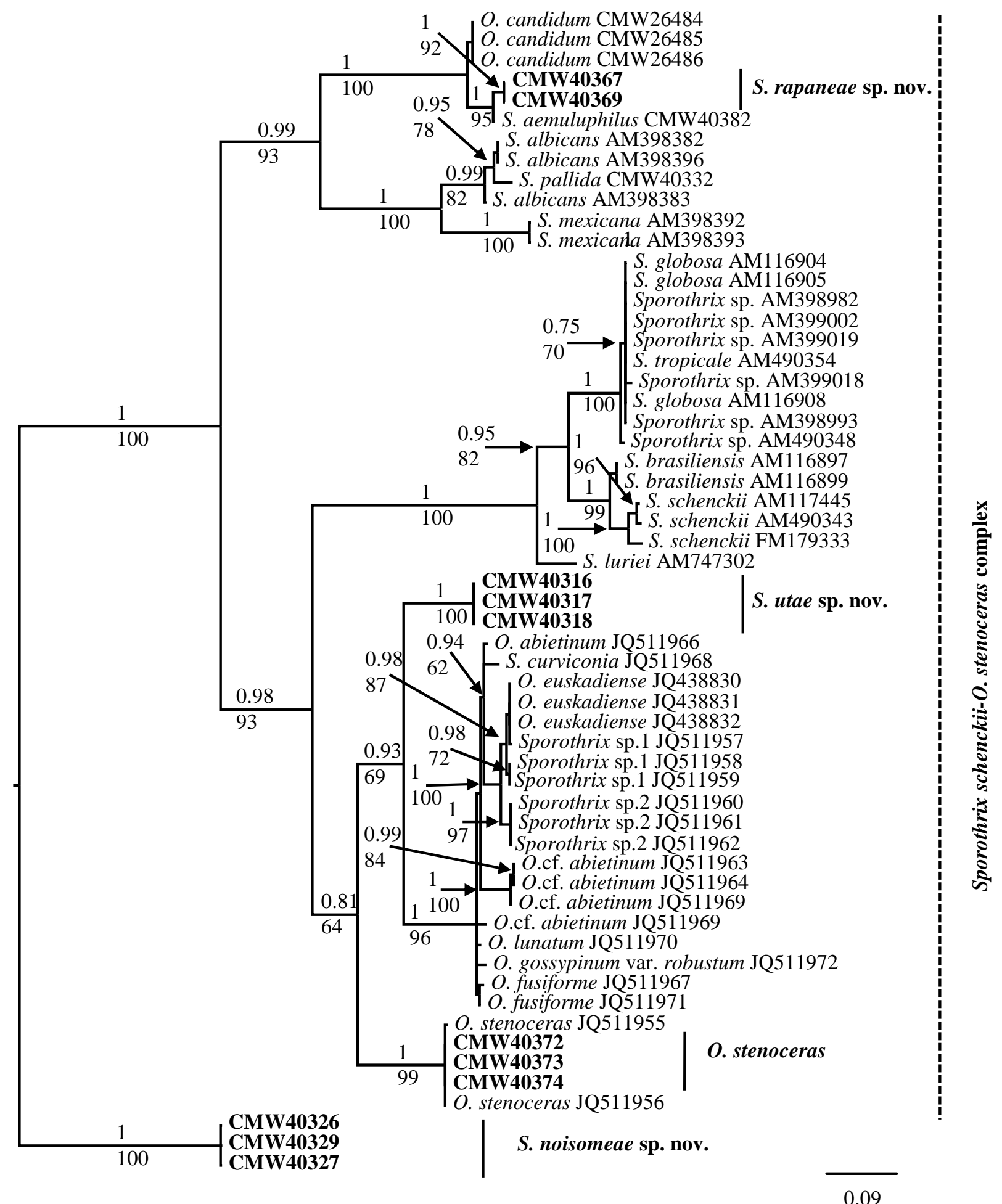

Fig. 3: Bayesian Inference consensus tree (CAL data) of taxa related to species isolated in the present study. Values above nodes indicate posterior probabilities obtained through Bayesian Inference. Values below nodes indicate bootstrap values (1000 replicates) obtained from Maximum Likelihood analysis. Isolates in bold were collected in this study. Other isolates [GenBank accession numbers and isolate numbers shown (when available)] were selected for comparative purposes 
Analyses of ITS, $\beta$ T and CAL data for OTU 2 collected from Groenkop forest (hereafter referred to as: Sporothrix rapaneae sp. nov.) resulted in trees with similar placement of its isolates than those of S. itsvoense. The ITS data did not distinguish between S. rapaneae, S. aemulophila and $O$. candidum, which formed a single group (Fig. 1). Analyses of the $\beta T$ data set showed that $S$. rapaneae grouped sister to $O$. candidum (Fig. 2), while analyses of the CAL dataset resulted in the isolates forming a strongly supported distinct taxon sister to S. aemulophila (Fig. 3).

Analyses of ITS data for OTU 3 collected from Weza Forest (hereafter referred to as: Sporothrix utae sp. nov.) resolved it as a distinct clade with strong support sister to O. aurorae X.D. Zhou \& M.J. Wingf and also closely related to a larger clade comprising of the species O. fusiforme D.N. Aghayeva \& M. J. Wingfield, O. lunatum D.N. Aghayeva \& M. J. Wingfield and O. abietinum Marmolejo \& Butin (Fig. 1). Analyses of $\beta$ T and CAL data proposed a similar placement of Sporothrix utae (Figs. 2 and 3), where it also grouped as a strongly supported distinct taxon sister to a large clade containing species such as $O$. fusiforme, $O$. lunatum and $O$. abietinum.

Operational taxonomic unit 4 from Weza Forest (hereafter referred to as: Ophiostoma noisomeae sp. nov.) grouped strongly as distinct taxon in analyses of all three data sets. Analyses of ITS data grouped it as sister to the genus Graphilbum (Fig. 1), while analyses of $\beta \mathrm{T}$ data grouped it as sister to the Sporothrix lignivora complex (De Beer \& Wingfield 2013) (Fig. 2). Analysis of CAL data strongly supported it as a distinct clade, but unfortunately CAL data for the above-mentioned closely related taxa was not available (Fig. 3). Analyses of ITS, $\beta$ T and CAL data showed that the OTU 5 grouped with isolates of Ophiostoma stenoceras (Robak) Nannf. with strong support (Fig. 1-3).

\section{Taxonomy}

Based on phylogenetic analyses and micro-morphological characteristics four of the five collected taxa (all except Ophiostoma stenoceras) were recognised as distinct, undescribed species. The three taxa belonging to the Sporothrix schenckiiOphiostoma stenoceras complex are described below as species of Sporothrix, as this complex will soon be redefined to represent the genus Sporothrix (Z.W. de Beer, 
personal communication), which is distinct from the genus Ophiostoma s.str. (De Beer \& Wingfield 2013). The fourth species that groups alongside, but not within Graphilbum and the S. lignivora complex, cannot be placed with confidence in any of these genera based on the ITS data. Until all genera in the Ophiostomatales are redefined based on more conserved gene regions, we follow the interim recommendations by De Beer \& Wingfield (2013) and describe the fourth species in Ophiostoma s.l::

Sporothrix itsvoense Musvuugwa, LL. Dreyer \& F. Roets sp. nov. Fig. 4.

Mycobank: MB816106.

Etymology: The epithet itsvoense (itsvo $=$ kidney in the African native Shona language) refers to the kidney-shaped ascospores produced by this species.

Ascomata superficial or embedded on the host substrate, bases globose, dark brown, ornamental hyphae present, 95-178 (134 \pm 28$) \mu \mathrm{m}$ diam; necks black, 384-777 (530 \pm

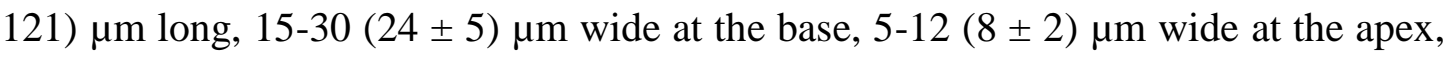
ostiolar hyphae hyaline, aseptate, glossy 13-17 (15 \pm 1.2$) \mu \mathrm{m}$ long (Fig. 4a, c and d). Asci evanescent. Ascospores kidney-shaped, aseptate, hyaline, sheaths absent, 1.3-2.4 $(1.84 \pm 0.46) \times 0.3-0.5(0.37 \pm 0.12) \mu \mathrm{m}$ (Fig. 4b), accumulating in a transparent gelatinous droplet at the apex of the neck, becoming dry when old. Colonies whitish to cream-coloured, on MEA fluffy in the centre only. Odourless, circular with entire edge (Fig. 4e). Colony diameter reaching $35.7( \pm 1.3) \mathrm{mm}$ after 10 days on MEA at an optimal growth temperature of $25^{\circ} \mathrm{C}$. No growth below $5^{\circ} \mathrm{C}$ or above $35^{\circ} \mathrm{C}$. Conidiophores mononematous, cylindrical, hyaline, 5.1-7.9 (6.18 \pm 1.24) x 0.5-1.1 $(0.83 \pm 0.28) \mu \mathrm{m}$ (Fig. 4f). Conidiogenous cells arising directly from tips of conidiophores, hyaline, forming denticles 0.5-1.3 (0.9 \pm 0.3) $\mu \mathrm{m}$ long (Fig. 4g). Conidia hyaline, aseptate, obovate, 3.4-4.4 (3.9 \pm 0.42$) \times 0.6-0.9(0.75 \pm 0.13) \mu \mathrm{m}$ (Fig. 4h).

Substrate: Isolated from damaged wood and inner bark of Rapanea melanophloeos

Distribution: South Africa, Western Cape Province 


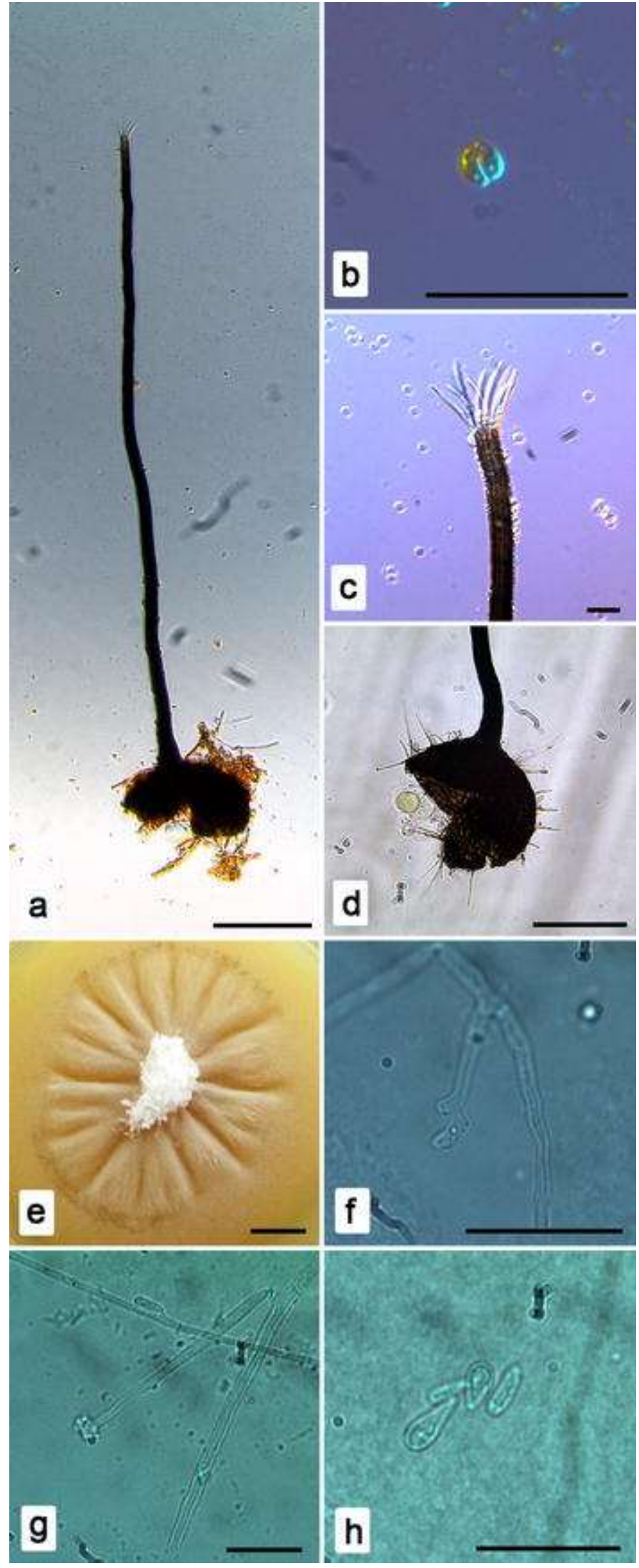

Fig. 4: Micrographs of Sporothrix itsvo. a Perithecium removed from the bark of Rapanea melanophloeos (scale bar $100 \mu \mathrm{m}$ ); b ascospores (scale bar $10 \mu \mathrm{m})$; $\mathbf{c}$ tip of perithecial neck (scale bar $10 \mu \mathrm{m})$; d globose base showing ornamental hyphae (scale bar $100 \mu \mathrm{m})$; e two-week-old colony on MEA at $25^{\circ} \mathrm{C}$ (scale bar $10 \mathrm{~mm}$ ); f conidiophores (scale bar $10 \mu \mathrm{m}$ ); $\mathbf{g}$ Conidiogenous cells showing denticles (scale bar $10 \mu \mathrm{m}) ; \mathbf{h}$ conidia (scale bar $10 \mu \mathrm{m})$ 
Specimens examined: South Africa, Western Cape Province, Harold Porter National Botanical Garden, Betty's Bay. Isolated from Rapanea melanophloeos, August 2010, T. Musvuugwa, holotype PREM 61325, culture ex-holotype CMW 40370= CBS 141063, paratype PREM 61327, culture ex-paratype CMW 47169= CBS 141077, paratype PREM 61326, culture ex-paratype CMW 40371 = CBS 141064.

Sporothrix rapaneae Musvuugwa, LL. Dreyer \& F. Roets sp. nov. Fig. 5.

Mycobank: MB816107

Etymology: The epithet rapaneae refers to the genus name of the host plant (Rapanea melanophloeos) from which this species was collected.

Ascomata superficial on the host substrate, bases globose, black, with no ornamental

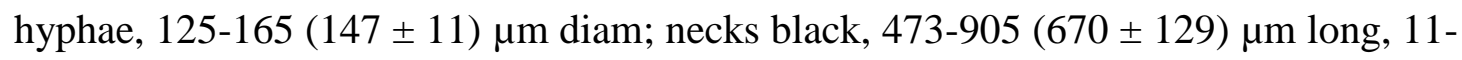
$30(24 \pm 5) \mu \mathrm{m}$ wide at the base, 3-6 (4 \pm 1$) \mu \mathrm{m}$ wide at the apex, ostiolar hyphae present, hyaline, aseptate, pale brown to glossy brown, 22-35 $\mu \mathrm{m}(26 \pm 3)$ long (Fig. 5a and c). Asci evanescent. Ascospores allantoid, slightly curved, aseptate, hyaline, 2.8-4.7 (3.75 \pm 0.98$) \times 0.3-0.6(0.45 \pm 0.13) \mu \mathrm{m}$ (Fig. 5b), accumulating in a sticky gelatinous droplet at the tip of the neck, becoming white to cream colored when dry. Colonies white, fluffy, on MEA, circular, edges entire (Fig. 5d). Colony diameter reaching $34.9( \pm 0.7) \mathrm{mm}$ after 10 days on MEA at an optimal growth temperature of $25^{\circ} \mathrm{C}$. No growth below $5^{\circ} \mathrm{C}$ or above $30^{\circ} \mathrm{C}$. Conidiophores hyaline, cylindrical, 4.1$7.9(5.95 \pm 1.59) \times 0.7-1.2(0.98 \pm 0.22) \mu \mathrm{m}$ (Fig. 5e). Conidiogenous cells forming directly from tips of conidiophores, hyaline, with prominent, denticles 0.4-1.3 (0.86 \pm 0.2) $\mu \mathrm{m}$ long (Fig. 5e). Conidia hyaline, aseptate, oblong, 3.9-5.5 (4.7 \pm 0.67) x 0.5$1.1(0.85 \pm 0.26) \mu \mathrm{m}$ (Fig. 5f).

Substrate: Isolated from inner bark of Rapanea melanophloeos

Distribution: South Africa, Western Cape Province

Specimens examined: South Africa, Western Cape Province, Groenkop. Isolated from Rapanea melanophloeos, October 2011, T. Musvuugwa, holotype PREM 61322, 


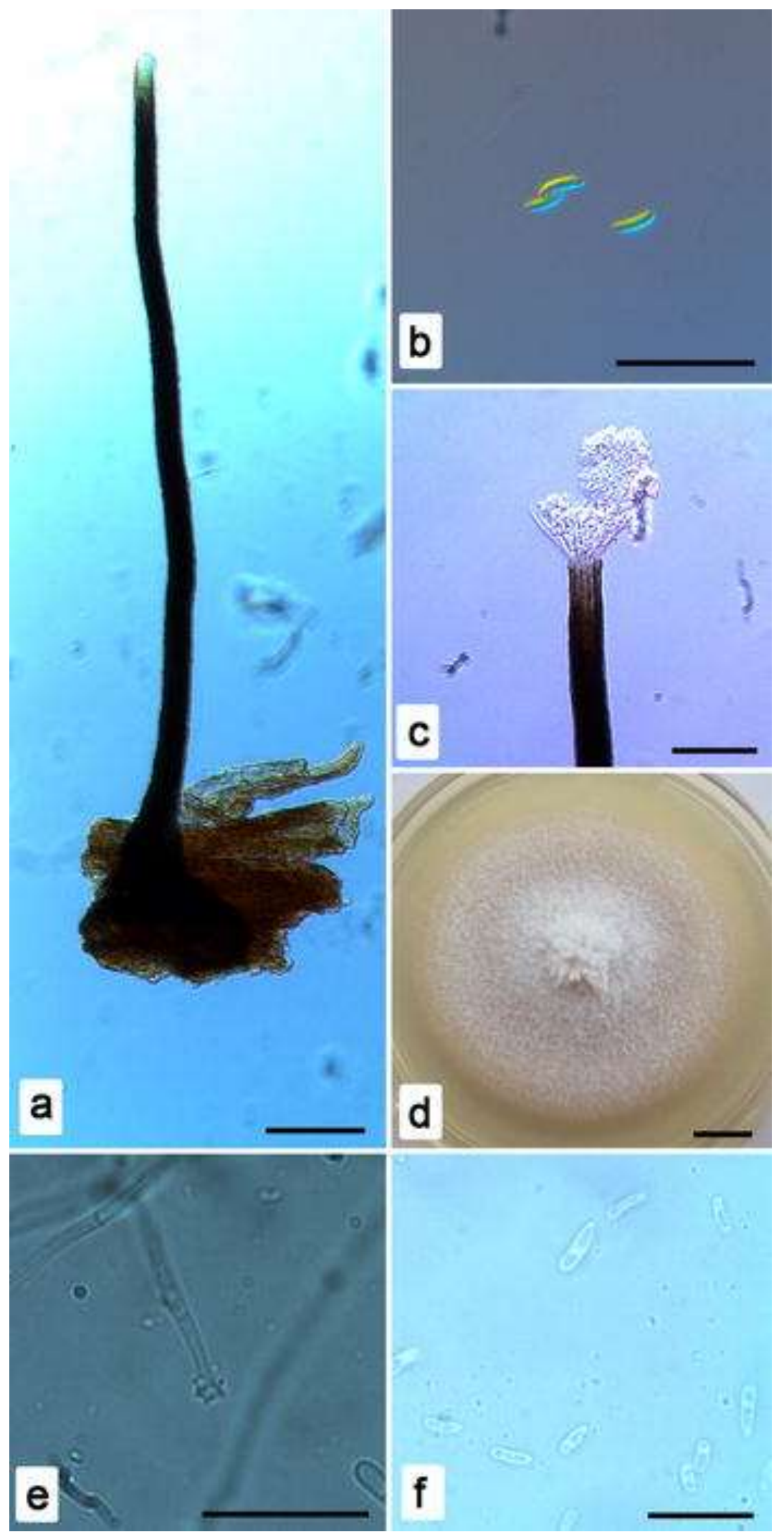

Fig. 5: Micrographs of Sporothrix rapaneae. a Perithecium removed from bark of Rapanea melanophloeos (scale bar $100 \mu \mathrm{m}$ ); b ascospores (scale bar $10 \mu \mathrm{m})$; $\mathbf{c}$ tip of perithecial neck (scale bar $10 \mu \mathrm{m})$; d two-week-old colony on MEA (scale bar $10 \mathrm{~mm}$ ); e conidiogenous cells showing prominent denticles (scale bar $10 \mu \mathrm{m})$; f conidia (scale bar $10 \mu \mathrm{m}$ ) 
culture ex-holotype CMW 40369 = CBS 141060, paratype PREM 61323, culture exparatype CMW $40367=$ CBS 141061, paratype PREM 61324, culture ex-paratype CMW $40368=$ CBS 141062.

Sporothrix utae Musvuugwa, LL. Dreyer \& F. Roets sp. nov. Fig 6.

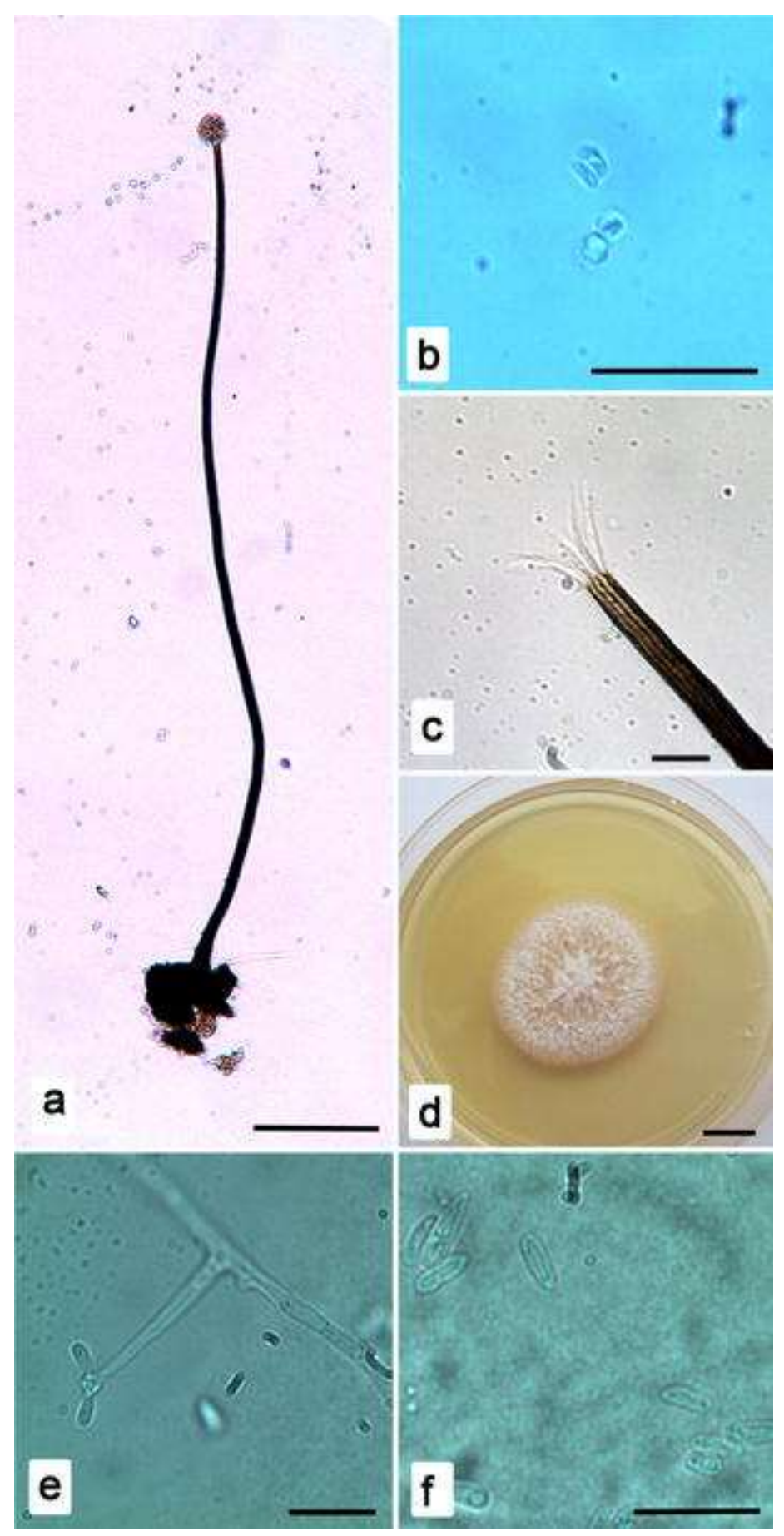

Fig. 6: Micrographs of Sporothrix uta. a Perithecium removed from bark of Rapanea melanophloeos (scale bar $100 \mu \mathrm{m}$ ); b ascospores (scale bar $10 \mu \mathrm{m}$ ); c tip of perithecial neck (scale bar $10 \mu \mathrm{m}$ ); $\mathbf{d}$ twoweek-old colony on MEA (scale bar $10 \mathrm{~mm}$ ); e conidiogenous cells showing prominent denticles (scale bar $10 \mu \mathrm{m})$; f conidia (scale bar $10 \mu \mathrm{m})$ 
Mycobank: MB816108

Etymology: The epithet utae $(\mathrm{uta}=$ crescent/bow shaped in the African native Shona language) refers to the crescent or bow-shaped ascospores produced by this species. Ascomata embedded or superficial on the host substrate, bases globose, brownish to black, with no hyphal ornamentation, 87-101 (94 \pm 5) $\mu \mathrm{m}$ diam; necks dark brown,

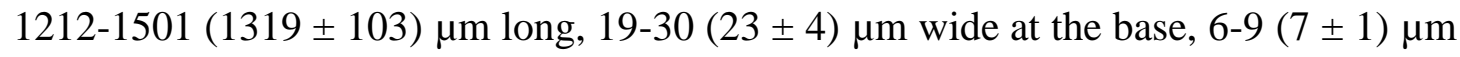
wide at the tip, ostiolar hyphae hyaline, aseptate, pale brown, 12-17 (15 \pm 2$)$ long (Fig. 6a, c). Asci evanescent. Ascospores crescent-shaped, hyaline, aseptate, 1.9-2.6 $(2.28 \pm 0.29) \times 0.5-0.8(0.65 \pm 0.13) \mu \mathrm{m}$ (Fig. 6b), accumulating transparent sticky masses at the apex of the neck, becoming white with age. Colonies white, fluffy appearance on MEA. Odourless, circular with entire edges (Fig. 6d). Colony diameter reaching $38( \pm 1.2) \mathrm{mm}$ after 10 days on MEA at optimal temperature of $25^{\circ} \mathrm{C}$. No growth below $5^{\circ} \mathrm{C}$ or above $35^{\circ} \mathrm{C}$. Conidiophores hyaline, cylindrical, 3.9-8 (5.7 \pm 2.1) x 0.9-1.4 (1.2 \pm 0.22) $\mu \mathrm{m}$ (Fig. 6e-f). Conidiogenous cells formed from tips of conidiophores, hyaline, with 0.9-2.8 (1.6 \pm 0.6$) \mu \mathrm{m}$ long denticles (Fig. 6e-f). Conidia hyaline, aseptate, oblong, 4.2-4.8 (4.5 \pm 0.26) x 0.7-1.2 (0.95 \pm 0.24$) \mu \mathrm{m}$ (Fig. 6f).

Substrate: Isolated from wood and inner bark of Rapanea melanophloeos

Distribution: South Africa, Western Cape Province

Specimens examined: South Africa, KwaZulu-Natal Province, Weza Forest Reserve. Isolated from Rapanea melanophloeos, September 2010, T. Musvuugwa, holotype PREM 61331, culture ex-holotype CMW 40318 = CBS 141068, paratype PREM 61332, culture ex-paratype CMW 40316= CBS 141069, paratype PREM 61333, culture ex-paratype CMW 40317 = CBS 141070.

Ophiostoma noisomeae Musvuugwa, LL. Dreyer \& F. Roets sp. nov. Fig. 7. 


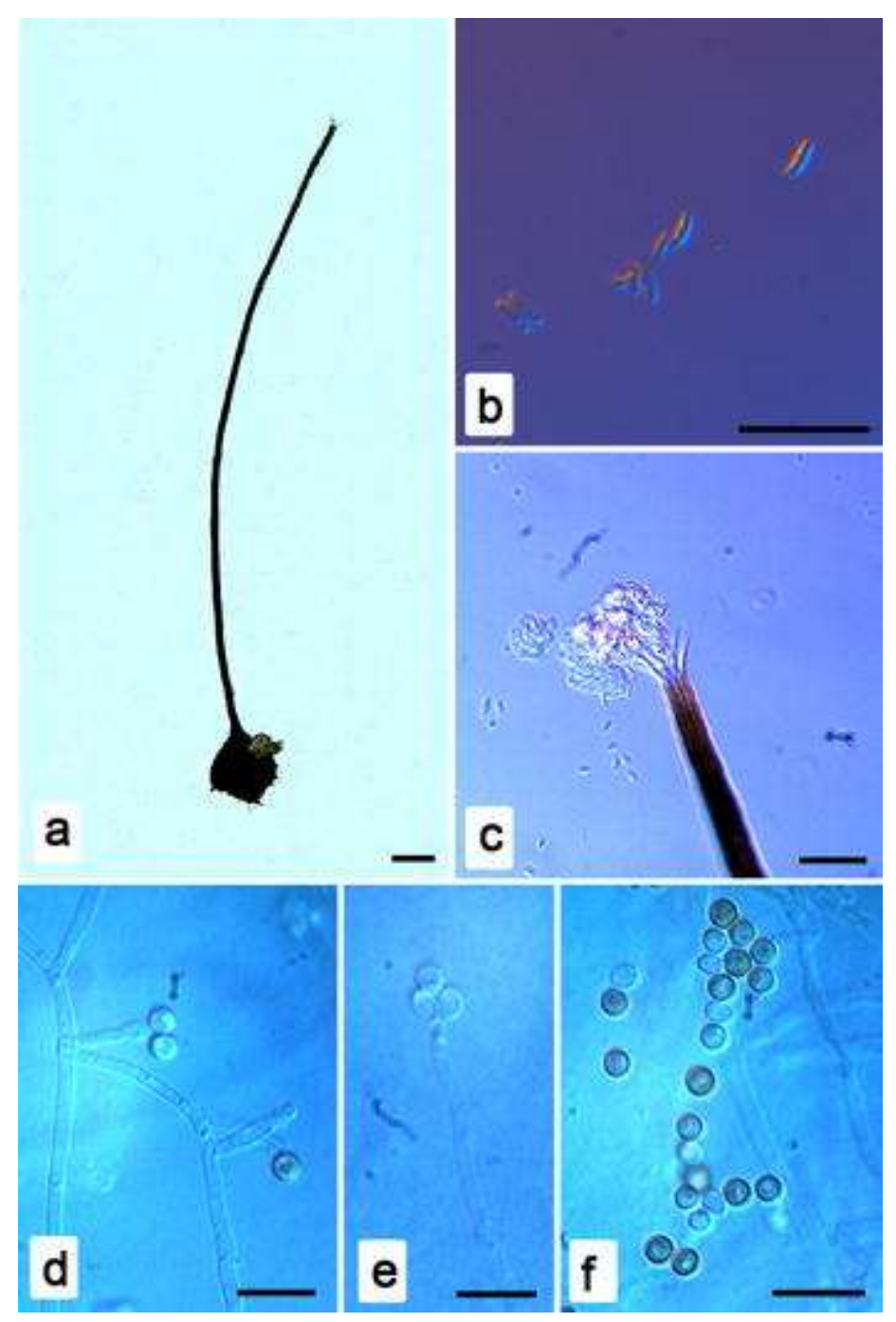

Fig. 7: Micrographs of Ophiostoma noisomeae. a Perithecium removed from bark of Rapanea melanophloeos (scale bar $100 \mu \mathrm{m}$ ); b ascospores (scale bar $10 \mu \mathrm{m}$ ); $\mathbf{c}$ tip of perithecial neck (scale bar $10 \mu \mathrm{m}) ; \mathbf{d}$, e conidiophores (scale bar $10 \mu \mathrm{m}) ; \mathbf{f}$ conidia (scale bar $10 \mu \mathrm{m}$ )

\section{Mycobank: MB816109}

Etymology: The epithet noisomeae (noisome = foal smell) refers to the foal smell produced by colonies of this species.

Ascomata superficial on host substrate, bases globose, black, with no ornamental

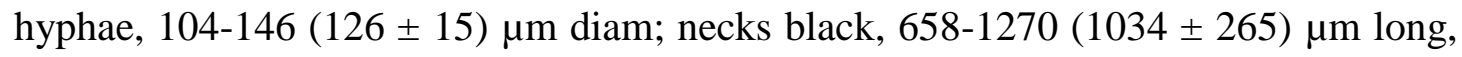
12-31 (23 \pm 5$) \mu \mathrm{m}$ wide at the base, 4-9 (7 \pm 1$) \mu \mathrm{m}$ wide at the apex, ostiolar hyphae hyaline, aseptate, glossy 24-33 (28 \pm 3) $\mu \mathrm{m}$ long (Fig. 7a, b). Asci evanescent. Ascospores allantoid, aseptate, hyaline, 2.0-2.6 (2.34 \pm 0.26$) \times 0.5-0.8(0.65 \pm 0.13)$ $\mu \mathrm{m}$, accumulating a gelatinous droplet at the tip of the neck, becoming whitish with age (Fig. 7c). Colonies white, turning blackish with age on MEA. Foal smelling when 
older, circular, edges entire (Fig 7d). Optimal growth at $25^{\circ} \mathrm{C}$ with a colony diameter of $28.7( \pm 1.1) \mathrm{mm}$ after 10 days on MEA. No growth below $5^{\circ} \mathrm{C}$ or above $30^{\circ} \mathrm{C}$. Conidiophores 18.3-21.4 (19.68 \pm 1.35) x 0.9-1.8 (1.35 \pm 0.39) $\mu \mathrm{m}$, hyaline, cylindrical (Fig. 7d-e). Conidiogenous cells arising from apex of conidiophores, hyaline (Fig. 7d). Conidia aseptate, hyaline, thin-walled, smooth, spherical, form in masses, becoming brownish with age, 2.2-3.8 (3.08 \pm 0.72$) \times 2.2-3.4(2.78 \pm 0.53) \mu \mathrm{m}$ (Fig. 7f).

Substrate: Isolated from wood and inner bark of Rapanea melanophloeos

Distribution: South Africa, KwaZulu-Natal

Specimens examined: South Africa, KwaZulu-Natal Province, Weza Forest Reserve. Isolated from Rapanea melanophloeos, September 2010, T. Musvuugwa, holotype PREM 61328, culture ex-holotype CMW 40326 = CBS 141065, paratype PREM 61329, culture ex-paratype CMW 40329 = CBS 141066, paratype PREM 61330, culture ex-paratype CMW 40327 = CBS 141067.

\section{Discussion}

This study reports five members of the Ophiostomatales associated with wounds on $R$. melanophloeos in Afromontane forests of South Africa. Four of these are newly described here (Sporothrix itsvoense, S. rapaneae, S. utae and Ophiostoma noisomeae). This demonstrates that there is a rich and yet still poorly studied diversity of Ophiostomatales associated with R. melanophloeos in Afromontane forests. The five reported species are in addition to several other species that have previously been isolated from wounds (Kamgan Nkuekam et al. 2008) and subcortical beetles (Musvuugwa et al. 2015) from the same host. This brings the total number of species in this order now known from this host to nine and includes Ophiostoma quercus, Graphilbum fragrans, Raffaelea rapaneae T. Musvuugwa, Z.W. de Beer, L.L. Dreyer and F. Roets, and Sporothrix aemulophila T. Musvuugwa, Z.W. de Beer, L.L. Dreyer and F. Roets (Kamgan Nkuekam et al. 2008; Musvuugwa et al. 2015). Given the relatively high number Ophiostomatales collected from $R$. melanophloeos from only a few studies in these forests, there is reason to believe that numerous additional species still await discovery with the inclusion of additional sites in future studies. 
Four of the species collected in this study belong to the S. schenckii-O. stenoceras complex (De Beer et al. 2013b), including three of the newly described species. This adds to an already high diversity of species in this complex from southern Africa (De Meyer et al. 2008; Kamgan Nkuekam et al. 2012; Musvuugwa et al. 2015; Roets et al. 2007, 2009; Zhou et al. 2006). This complex includes species collected from many different substrates, including mite-associated species from Protea infructescences (Roets et al. 2007, 2009), human pathogens (Marimon et al. 2007) and subcortical beetle-associated species (Musvuugwa et al. 2015). Many taxa are also known from "environmental" samples such as soil, air and decaying wood (De Beer and Wingfield 2013b). The ecology of species in this complex thus varies greatly and it would be interesting to determine the ecological role of the taxa associated with wounds on Rapanea.

Sporothrix itsvoense was collected from Rapanea hosts in indigenous forests surrounding the Harold Porter National Botanical Garden. The species is closely related to $S$. aemulophila, a recently described species from the same $R$. melanophloeos host (Musvuugwa et al. 2015). Sporothrix aemulophila is an associate of the ambrosia beetle Xyleborinus aemulus Wollaston (Scolytinae) that infest $R$. melanophloeos trees at the same site (Harold Porter National Botanical Garden) from which S. itsvoense was collected (Musvuugwa et al. 2015). Besides being isolated from the same host tree and from the same area, these two taxa are also similar in characters such as the presence of ostiolar hyphae and similar colony growth forms on MEA (Musvuugwa et al. 2015). The two species differ in other traits such as the presence of ornamental hyphae on perithecial bases in S. itsvoense, which are absent in $S$. aemulophila and the kidney-shaped ascospores in $S$. itsvoense, while $S$. aemulophila has allantoid-shaped spores (Musvuugwa et al. 2015).

Sporothrix rapaneae was collected from Groenkop forest and analyses of $\beta \mathrm{T}$ and CAL data resolved it as sister to $O$. candidum and $S$. aemulophila, respectively. The relationship with $S$. aemulophila was, however, more strongly supported than that with $O$. candidum. Similarities shared with $S$. aemulophila include the presence of ostiolar hyphae and the production of allantoid-shaped ascospores. Sporothrix rapaneae differs from $S$. aemulophila in its optimal growth temperatures $\left(30^{\circ} \mathrm{C}\right.$ for $S$. aemulophila and $25^{\circ} \mathrm{C} \mathrm{S}$. rapaneae) and average sizes of morphological structures 
(Musvuugwa et al. 2015). Sporothrix rapaneae and S. aemulophila differ from $O$. candidum in basal ornamentation of perithecia, which is present in O. candidum, but absent in $S$. rapaneae, the production of ascomata on MEA by $O$. candidum, but not by $S$. rapaneae as well as in average sizes of morphological structures (Kamgan Nkuekam et al. 2012). They are similar in having the same optimal growth temperatures and the presence of ostiolar hyphae (Kamgan Nkuekam et al. 2012). Phylogenetic analyses of the three gene regions suggest that Sporothrix utae is closely related to several species (e.g. O. fusiforme, O. lunatum and O. abietinum), although ITS data showed it to be sister to O. aurorae. Ophiostoma aurorae was isolated from root-feeding Hylastes angustatus Herbst that infest Pinus patula Schiede \& Deppe in South Africa (Zhou et al. 2006). It is characterised by bases ornamented with light grey hyphae and allantoid ascospores (Zhou et al. 2006). These characters differentiate it from $S$. utae. Several species closely related to $S$. utae are woodinhabiting (De Beer et al. 2013b). Ophiostoma fusiforme, for example, was isolated from Populus nigra L. and Quercus petraea (Matt.) Liebl. in Azerbaijan and Austria, respectively. Ophiostoma lunatum is known from Austria, where it was isolated from Carpinus betulus L. and Larix decidua Mill., while $O$. abietinum was isolated from pine wood (Aghayeva et al. 2004). Although they are all wood inhabiting species with Sporothrix-like anamorphs and share other similarities such as the presence of ostiolar hyphae, they differ in several traits such as their basal hyphal ornamentation (present in $O$. fusiforme and $O$. lunatum), the shape of their ascospores and the average measurements of morphological structures (Aghayeva et al. 2004).

The isolates of Ophiostoma stenoceras collected in this study were from Weza Forest. It is a well-known sapwood colonising fungus that was first described in Norway from ground wood pulp (Robak 1932), but are now known from several hardwood and coniferous hosts, mostly in the Northern Hemisphere (Griffin 1968). This wide host range is reflected in the existence of several synonyms for this species, including O. albidum Math.-Käärik, Ceratocystis gossypina var. robusta T.E. Hinds \& R.W. Davidson, O. ponderosae (T.E. Hinds \& R.W. Davidson) Hausner, J. Reid \& Klassen, and Ceratocystis eucastaneae R.W. Davidson (De Beer et al. 2003b). Ophiostoma stenoceras has previously also been collected in the Southern Hemisphere, although only from non-native hosts such as Pinus spp. in New Zealand (Schirp et al. 1999) and Eucalyptus spp. in South Africa (De Beer et al. 2003). 
Although this species causes gray staining of pine wood (Käärik 1980), it is not considered economically important (Griffin 1968).

Ophiostoma noisomeae, the other newly described species from Weza Forest, groups between Graphilbum and the Sporothrix lignivora complex based on ITS data. The $\beta$ T intron composition of $O$. noisomeae is (3/4/5), while that of the S. lignivora complex is $-/ 4 / 5$ and that of the $S$. schenckii-O. stenoceras complex is $3 /-/ 5$ or $-/-/ 5$ (De Beer et al. (2013b). However, in the $\beta T$ data set used for our analyses, only data for exons 4, 5, and 6, interspersed with introns 4 and 5, were included. This explains why $O$. noisomeae grouped closer to the S. lignivora complex (Fig. 2). Based on CAL data, $O$. noisomeae formed a distinct clade, but its affinities are unclear as CAL data of S. lignivora and Graphilbum species are still lacking. Our analyses support results of De Beer et al. (2013b) and Linnakoski et al. (2010) that the S. lignivora complex and $O$. noisomeae form distinct lineages with significant distance from other genera and complexes in the Ophiostomatales. De Beer et al. (2013b) suggested that, due to the distance at which the $S$. lignivora complex groups from other complexes and genera in the Ophiostomatales, the group may represent a separate genus. There is, however, uncertainty about the phylogenetic placement of this group as it differs depending on the specific marker used (De Beer et al. 2013b). Sequences for more conservative gene regions will be required to determine the exact generic placements of the S. lignivora complex and $O$. noisomeae.

The frequency of occurrence on wounds was highest for $O$. noisomeae and lowest for O. stenoceras. Although not tested here this may be very relevant if it is shown that species with high frequency of occurrence is also pathogenic to $R$. melanophloeos and could become problematic with increased creation of wounds for bark harvesting. This high frequency also point towards mechanisms that allow these species to easily disperse and infect wounds. Future studies should focus on determining the dispersal mechanisms of the different Ophiostomatales species between wounds to verify whether differences in their frequency of occurrence may be related to the abundance/dispersal abilities of the main vectors involved and/or whether different fungal taxa may prefer different aged wounds (i.e. succession studies). 
In this study we collected five members of the Ophiostomatales, including four new species, associated with wounds on $R$. melanophloeos. Four of the species belong to the S. schenckii-O. stenoceras complex, while the fifth species groups basal in the Ophiostomatales alongside the S. lignivora complex and Graphilbum. Based on these results and those from previous studies, there is evidence of a relatively high diversity of Ophiostomatales associated with this host tree in the Afromontane forests of South Africa. It is recommended that future studies investigate the total number of taxa associated with this important tree, and that the pathogenicity of all the taxa towards this host is determined. If many prove to be virulent pathogens, conservation managers may need to restrict bark harvesting activities of this species.

\section{References}

Aghayeva DN, Wingfield MJ, De Beer ZW, Kirisits T (2004) Two new Ophiostoma species with Sporothrix anamorphs from Austria and Azerbaijan. Mycologia 96: 866878

Akaike H (1974) A new look at the statistical model identification. IEEE Trans Autom Control 19: 716-723

Altschul SF, Gish W, Miller W, Myers EW, Lipman DJ (1990) Basic local alignment search tool. J Mol Biol 215: 403-410

Brasier CM (2008) The biosecurity threat to the UK and global environment from international trade in plants. Plant Pathol 57: 792-808

Brasier CM (2000) Intercontinental spread and continuing evolution of the Dutch elm disease pathogens. In: Dunn, CP (ed) The elms: Breeding, Conservation and Disease Management, Kluwer Academic Publishers, Boston, USA, Dordrecht, The

Netherlands, London, UK, pp 61-72

Brasier CM, Buck KW (2001) Rapid evolutionary changes in a globally invading fungal pathogen (Dutch elm disease). Biol Invasions 3: 223-233

Castello JD, Leopold DJ, Smallidge PJ (1995) Pathogens, patterns and processes in forest ecosystems. BioScience 45: 16-24

Chen SF, Wingfield MJ, Roets F, Roux J (2013) A serious canker disease caused by Immersiporthe knoxdaviesiana gen. et sp. nov. (Cryphonectriaceae) on native Rapanea in South Africa. Plant Pathol 62: 667-678 
De Beer ZW, Wingfield MJ (2013) Emerging lineages in Ophiostomatales. In: Seifert KA, De Beer ZW, Wingfield MJ (eds) Ophiostomatoid fungi: expanding frontiers, CBS Biodiversity Series 12, pp. 21-46.

De Beer ZW, Seifert KA, Wingfield MJ (2013a) The ophiostomatoid fungi: their dual position in the Sordariomycetes. In: Seifert KA, De Beer ZW, Wingfield MJ (eds) Ophiostomatoid fungi: expanding frontiers, CBS Biodiversity Series 12, pp 1-19 De Beer ZW, Seifert KA, Wingfield MJ (2013b) A nomenclature for ophiostomatoid genera and species in the Ophiostomatales and Microascales. In: Seifert KA, De Beer ZW, Wingfield MJ (eds) Ophiostomatoid fungi: expanding frontiers, CBS

Biodiversity Series 12, pp 245-322

De Beer ZW, Wingfield BD, Wingfield MJ (2003) The Ophiostoma piceae complex in the southern hemisphere: a phylogenetic study. Mycol Res 107: 469-476

De Meyer EM, De Beer ZW, Summerbell RC, Moharram AM, De Hoog GS, Vismer HF, Wingfield MJ (2008) Taxonomy and phylogeny of new wood- and soil-inhabiting Sporothrix species in the Ophiostoma stenoceras-Sporothrix schenckii complex. Mycologia 100: 647-661

Duong TA, De Beer ZW, Wingfield BD, Wingfield MJ (2012) Phylogeny and taxonomy of species in the Grosmannia serpens complex. Mycologia 104: 715-732

Gardes M, Bruns TD (1993) ITS primers with enhanced specificity for basidiomycetes application to the identification of mycorrhizae and rusts. Mol Ecol 2: $113-11$

Gibbs JN (1993) The biology of Ophiostomatoid fungi causing sapstain in trees and freshly cut logs. In: Wingfield MJ, Seifert KA, Webber JF (eds) Ceratocystis and Ophiostoma : Taxonomy, Ecology, and Pathogenicity, American Phytopathological Society Press, St. Paul, Minnesota, pp 153-160

Glass NL, Donaldson GC (1995) Development of primer sets designed for use with the PCR to amplify conserved genes from filamentous Ascomycetes. Appl Environ Microbiol 61: 1323-1330

Griffin HD (1968) The genus Ceratocystis in Ontario. Can J Bot 46: 689-718

Guindon S, Gascuel O (2003) A simple, fast, and accurate algorithm to estimate large phylogenies by maximum likelihood. Syst Biol 52: 696-704

Harrington TC (1993) Biology and taxonomy of fungi associated with bark beetles. In: Schowalter TD and Filip GM (eds) Beetle-pathogen interactions in conifer forests, Academic Press, NY, pp. 37-58. 
Harrington TC (1981) Cycloheximide sensitivity as a taxonomic character in Ceratocystis. Mycologia 73: 1123-1129

Harrington TC, Fraedrich SW, Aghayeva DN (2008) Raffaelea lauricola, a new ambrosia beetle symbiont and pathogen on the Lauraceae. Mycotaxon 104: 399-404 Harrington TC, Wingfield MJ (1998) The Ceratocystis species on conifers. Can J Bot 76: $1446-1457$

Heybroek, HM (1993) Why bother about the elm? In: Sticklen MB, Sherald JL (eds)

Dutch Elm Disease Research. Cellular and Molecular Approaches, Springer-Verlag, New York , pp 1-8

Hinds TE (1972) Insect transmission of Ceratocystis species associated with Aspen cankers. Phytopathology 62: 221-225

Jacobs K, Wingfield MJ (2001) Leptographium species: Tree pathogens, insect associates, and agents of blue-stain. APS press, U.S.A.

Käärik A (1960) Growth and sporulation of Ophiostoma and some other blueing fungi on synthetic media. Symbolae Botanicae Upsalienses 16:1-168

Kamgan Nkuekam G, De Beer ZW, Wingfield MJ, Roux J (2012) A diverse assemblage of Ophiostoma species, including two new taxa on eucalypt trees in South Africa. Mycol Prog 11: 515-533

Kamgan Nkuekam G, Jacobs K, De Beer ZW, Wingfield MJ, Roux J (2008) Ceratocystis and Ophiostoma species including three new taxa, associated with wounds on native South African trees. Fungal Divers 29: 37-59

Katoh K, Toh H (2008) Recent developments in the MAFFT multiple sequence alignment program. Brief Bioinform 9: 286-298

Kubono T, Ito S (2002) Raffaelea quercivora sp. nov. associated with mass mortality of Japanese oak, and the ambrosia beetle (Platypus quercivorus). Mycoscience 43: 255-260

Linnakoski R, De Beer ZW, Athiainen J Sidorov E, Niemela P, Pappinen A,Wingfield MJ (2010) Ophiostoma spp. associated with pine and spruce-infesting bark beetles in Finland and Russia. Persoonia 25: 72-93

Lubke RA, Mackenzie B (1996) Afromontane Forest. In: Low AB, Rebelo GA (eds) Vegetation of South Africa, Lesotho and Swaziland, Department of Environmental Affairs and Tourism, Pretoria, p 12 
Malloch D, Blackwell M (1993) Dispersal biology of the ophiostomatoid fungi. In:Wingfield MJ, Seifert KA, Webber JF (eds) Ceratocystis and Ophiostoma: taxonomy, ecology and pathogenicity, APS Press, St. Paul, U.S.A, pp 195-206 Marais GJ, Wingfield MJ (2001) Ophiostoma africanum sp. nov., and a key to ophiostomatoid species from Protea infructescences. Mycol Res 105: 240-246 Marais GJ, Wingfield MJ (1997) Ophiostoma protearum sp. nov. associated with Protea caffra infructescences. Can J Bot 75: 362-367

Marimon R, Cano J, Gene J, Sutton DA, Kawasaki M, Guarro J (2007) Sporothrix brasiliensis, S. globosa, and S. mexicana, three new Sporothrix species of clinical interest. J Clin Microbiol 45: 3198-3206

Moller WJ, Devay JE (1968) Insect transmission of Ceratocystis fimbriata in deciduous fruit orchards. Phytopathology 58: 1499-1507

Musvuugwa T, De Beer WZ, Duong TA, Dreyer LL, Oberlander KC, Roets F (2015) New species of Ophiostomatales from scolytine beetles in the Cape Floristic Region, including the discovery of the sexual state of Raffaelea. A Van Leeuw J Microb. doi: $10.1007 / \mathrm{s} 10482-015-0547-7$

O’Donnell K, Cigelnik E (1997) Two divergent intragenomic rDNA ITS2 types within a monophyletic lineage of the fungus Fusarium are nonorthologous. Mol Phylogenet Evol 7: 103-116

Pipe ND, Brasier CM, Buck KW (2000) Evolutionary relationships of the Dutch elm disease fungus Ophiostoma novo-ulmi to other Ophiostoma species investigated by restriction fragment length polymorphism analysis of the rDNA region. J Phytopath 148: $533-539$

Posada D (2008) Selection of models of DNA evolution with jModelTest. In: Posada D (ed) Bioinformatics for DNA sequence analysis. Humana Press, Totowa, pp 93-112 Robak H (1932) Investigations regarding fungi on Norwegian ground wood pulp and fungal infection at wood pulp mills. Nyt Mag Naturvid 71: 185-330

Roets F, Dreyer LL, Crous PW, Wingfield MJ (2009) Mite-mediated hyperphoretic dispersal of Ophiostoma spp. from the infructescences of South African Protea spp. Environ Entomol 38: 143-152

Roets F, De Beer ZW, Wingfield MJ, Crous PW, Dreyer LL (2008) Ophiostoma gemellus and Sporothrix variecibatus from mites infesting Protea infructescences in South Africa. Mycologia 100: 496-510 
Roets F, Wingfield MJ, Crous PW, Dreyer LL (2007) Discovery of fungus-mite mutualism in a unique niche. Environ Entomol 36: 1226-1237

Roets F, de Beer ZW, Dreyer LL, Zipfel R, Crous PW, Wingfield MJ (2006) Multigene phylogeny for Ophiostoma spp. reveals two new species from Protea infructescences. Stud Mycol 55: 199-212

Ronquist FR, Huelsenbeck JP (2003) MrBayes: Bayesian phylogenetic inference under mixed models. Bioinformatics 19: 1572-1574

Schirp A, Farrell RL, Kreber B (1999) Effect of New Zealand staining fungi on structural wood integrity of radiata pine. The $2^{\text {nd }}$ New Zealand Sapstain Symposium. Proceedings of Symposium, Rotorua, New Zealand, 18-19 November, FRI Bull 215: 99-104 Seifert KA (1993) Sapstain of commercial lumber by species of Ophiostoma and Ceratocystis. In: Wingfield MJ, Seifert KA and Webber JF (eds) Ceratocystis and Ophiostoma. taxonomy, ecology and pathogenicity.. American Phytopathological Society Press, St. Paul, MN, pp. 141-151.

Seifert SA, Wingfield MJ, Kendrick WB (1993). A nomenclature for described species of Ceratocystis, Ophiostoma, Ceratocystiopsis, Ceratostomella and Sphaeromella. In: Wingfield MJ, Seifert KA, Webber J (eds) Ceratocystis and Ophiostoma: Taxonomy, Ecology and Pathogenicity, American Phytopathological Society, St. Paul, Minnesota, U.S.A, pp 269-287

Taylor JE, Lee S, Crous PW (2001) Biodiversity in the Cape Floral Kingdom: fungi occurring on Proteaceae. Mycol Res 105: 1480-1484

Turpie JK, Heydenrych BJ, Lamberth SJ (2003) Economic value of terrestrial and marine biodiversity in the Cape Gloristic Region: implications for defining effective and socially optimal conservation strategies. Biol Cons 112: 233-251 VanWyk B, VanWyk P (1997) Field Guide to Trees of Southern Africa. Struik Publishers, Cape Town, South Africa

Vermeulen WJ, Geldenhuys CJ, Esler KJ (2012) Response of Ocotea bullata, Curtisia dentata and Rapanea melanophloeos to medicinal bark stripping in the southern Cape, South Africa: implications for sustainable use. Southern Forests 74: 183-193

Webber JF, Jacobs K, Wingfield MJ (1999) A re-examination of the vascular wilt pathogen of takamaka (Colophyllum inophyllum). Mycol Res 103: 1588-1592 White TJ, Bruns T, Lee S, Taylor J (1990) Amplification and direct sequencing of fungal ribosomal RNA genes for phylogenetics. In: Innis MA, Gelfand DH, Sninsky 
JJ, White TJ (eds) PCR Protocols: A sequencing guide to methods and applications, Academic Press, San Diego, pp 315-322

Wingfield MJ, Seifert KA, Webber JA (1993) Ceratocystis and Ophiostoma:

Taxonomy, Ecology and Pathogenicity. APS Press, St Paul, MN, USA

Zhou XD, De Beer ZW, Wingfield MJ (2006) DNA sequence comparisons of

Ophiostoma spp., including Ophiostoma aurorae sp. nov., associated with pine bark beetles in South Africa. Stud Mycol 55: 269-277 